Supramolecular Structure and Function 8 


\section{Supramolecular Structure and Function 8}

Edited by

\section{Greta Pifat-Mrzljak}

Ruder Bošković Institute

Zagreb, Croatia 
eBook ISBN: $\quad 0-306-48662-8$

Print ISBN: $\quad$ 0-306-48661-X

C2005 Springer Science + Business Media, Inc.

Print C2004 Kluwer Academic/Plenum Publishers

Boston

All rights reserved

No part of this eBook may be reproduced or transmitted in any form or by any means, electronic, mechanical, recording, or otherwise, without written consent from the Publisher

Created in the United States of America

Visit Springer's eBookstore at:

http://ebooks.kluweronline.com

and the Springer Global Website Online at:

http://www.springeronline.com 


\section{Preface}

An enormous amount of new knowledge on the molecular basis of various biological phenomena has emerged in the rapidly expanding field of bioscience. Since the frontiers in scientific research are difficult to define, the creation of new knowledge depends not only on new methods and concepts but also on interaction with other fields of research. The principles and methods of biophysics should be a rational language for discussion not only between scientists of the different disciplines of natural sciences, such as physics, mathematics, biochemistry, molecular biology and biotechnology, but also for medicine and social sciences as well. This is the general philosophy behind the organization of the Summer Schools organized by Rudjer Bošković Institute, Zagreb, Croatia and the Croatian Biophysical Society.

The International Summer Schools on Biophysics have a very broad scope. This is in contrast to the other workshops or schools which are centred mainly on one topic or technique. The intention was to organize courses which provided advanced training at doctoral or postdoctoral level in biosciences. Therefore, the Schools essentially have a catalytic role and are complementary to, rather than competing with, activities of parallel national or international programmes.

Internationally recognized and successfully established these eight international summer schools have been organized under the title «Supramolecular Structure and Function». The Schools were devoted to the structure-function relationship of biological macromolecules and to mayor biophysical techniques. The Biophysics Schools provide a significant contribution to the capacity building of science in Europe. This is in line with UNESCO's declaration that, "it should be increased, support to regional and international programmes of higher education and to networking of graduate and postgraduate institutions". The organizers are deeply committed to the idea that science, scientific and educational collaborations help to create the European framework we all want to be a part of. These summer schools, as Master Classes of UNESCO, supported 
by IUPAB and UNESCO, could be a part of the mosaic forming the European Research Area (ERA) and the European Higher Education Area (EHEA). The organizers of the International Summer School on Biophysics think, therefore, that the publication of this volume and its distribution within the scientific community will serve towards the objectives of expanding, sharing and providing easy access to scientific knowledge.

The publication of the volume is due to the substantial financial support provided by the UNESCO Venice Office - Regional Office for Science and Technology for Europe (UVO-ROSTE) as well as by the intellectual efforts of Prof. Greta Pifat-Mrzljak from the Ruđer Bosković Institute - initiator of the series of the International Schools on Biophysics and Chairperson of the 8th School held in Rovinj in 2003.

Organizing Committee 


\section{Contents}

1. Structural Basis of Protein Synthesis

Christiane Schaffitzel and Nenad Ban 1

2. The Relationship Between Protein Sequence, Structure and

Function: Protein Function Prediction

Anna Tramontano andDomenico Cozzetto

3. Differences in Binding of Stereoisomers to Protein Active Sites Gerhard Klebe

4. Analytical Centrifugation: Looking at Aggregation in Free Solution P. Jonathan G. Butler

5. Time Resolved Protein Fluorescence. Application to Multi-

Tryptophan Proteins

Yves Engelborghs

6. Novel (Bio)chemical and (Photo)physical Probes for Imaging

Living Cells

Elizabeth A. Jares-Erijman, Carla Spagnuolo, Luciana Giordano, Maria Etchehon, Jennifer Kawior, Maria V. Mañalich-Arana, Mariano Bossi, Diane S. Lidke, Janine N. Post, Rudolf J. Vermeij, Rainer Heintzmann,Keith A. Lidke, Donna J. Arndt-Jovin, and Thomas M. Jovin

7. Observing Structure and Dynamics of Membrane Proteins

by High-resolution Microscopy

Andreas Engel

8. A 2D-Infrared Study of Human Lipoproteins

Xabier Cotto, Ibón Iloro, and José Luis R. Arrondo 
9. An Introduction to Biological Solid State NMR Andrew Dodd and Frances Separovic

10. Multi-Frequency EPR Spectroscopy Studies of the Structure and Conformational Changes of Site-Directed Spin Labelled Membrane Proteins

Heinz-Jürgen Steinhoff

11. Identification of Protein Structure and its Modifications by Electrospray Mass Spectrometry in Proteomics Jasna Peter-Katalinić

12.A Microscopic Study of Disorder-Order Transitions in Molecular Recognition of Unstructured Proteins: Hierarchy of Structural Loss and the Transition State Determination from Monte Carlo Simulations of P27KIP1 Protein Coupled Unfolding and Unbinding Gennady M. Verkhivker

13. Computational Detection of the Binding Site Hot Spot and Predicting Energetics of Ligand Binding at the Remodeled Human Growth Hormone-Receptor Interface Using a Hierarchy of Molecular Docking and Binding Free Energy Approaches Gennady M. Verkhivker

14. Molecular and Cellular Levels of Biological Evolution Miroslav Radman 